\title{
Analyzing Board Characteristics, Ownership Structure and Company Characteristic to Corporate Social Responsibility Disclosure
}

\author{
Asyifa Dea Kirana ${ }^{1}$ and Andrian Budi Prasetyo *2 \\ ${ }^{12}$ Department of Accounting, Universitas Diponegoro, Indonesia
}

\begin{abstract}
ARTICLE INFO
Article History:

Received October $19^{\text {th }}, 2020$

Accepted March 5 ${ }^{\text {th }}, 2021$

Available March 15 $5^{\text {th }}, 2021$

\section{Keywords:}

CSR Disclosure; Board

Characteristics; Ownership

Structure; Company

Characteristics; Sustainability

Report

ABSTRACT

This study aims to analyze the effect of board characteristics, ownership structure and company characteristics on CSR disclosure. The population of this study are non-financial companies that listed on the Indonesia Stock Exchange (IDX) which issues sustainability reports separately from the annual report for the year 2017-2018. Based on the purposive sampling method as a method of data collection, a total of 20 non-financial companies have published sustainability reports separately from the annual reports for 2017 and 2018 respectively. Multiple regression analysis used to test the research hypotheses. The results of this study indicate that the proportion of women on the board, board of director ownership concentration, profitability and leverage negatively affect the CSR, while the rest of variables does not affect the CSR disclosure. This result can be influenced by the small sample used, so that it can give different results from the suggested hypothesis. This study contributes in proving that differences in corporate governance between countries, the sample and the study period do not influence the characteristics of corporate governance, namely the board and ownership structure in influencing the corporate social responsibility disclosure.
\end{abstract}

(C) 2021 Published by UNNES. This is an open access article under the CC BY license (http://creativecommons.org/licenses/by/4.0/)

\section{INTRODUCTION}

The development of businesses from each year has caused many issues regarding business activities carried out by companies. One of that issues is Corporate Social Responsibility. This issue is based on the demands from the stakeholders which are, investors, debtholder, the society, and the government towards businesses so that they will not only focus on their economic successes through their profits, but also concern themselves with the impact from their business activities. Hence, the stakeholder's judgment of a company's success is not only determined through the company's financial performance, but also the company's care towards social problems and its surroundings. Siregar \& Bachtiar (2010) added that these days, many organizations think that reports of companies' financial performances will not satisfy the stakeholders. Therefore, this social responsibility is used by companies to balance out their financial aims, which is profit with their non-financial aims, one of them is to act accordingly to the interest of the people, environment, employees and also the customers where the company is running its business (Qa'dan

\footnotetext{
*E-mail: andrianbp1589@live.undip.ac.id

_Address: Jl. H. Prof Soedarto, SH - Tembalang Semarang Indonesia 50275
}

\& Suwaidan, 2018). Using that demand, a set of rules and laws were created in order to oversee companies' responsibilities to be socially responsible to the society and the environment. In Indonesia, this responsibility is backed with Company Act no. 40 year 2007.

Based on the demands and laws, companies have realized that as a form of an entity that operates within an environment, they must be held responsible for the consequences that could show up from their business activities that could make a negative impact towards the environment. This realization makes social responsibility as company's commitment to take part in sustainable economy development (Fahmi, 2017), which is proved through reports created by the company. Social responsibility disclosure is done to give evidence that a company has been actually responsible to the society and environment. However, every company's reports have different levels of revelation in their disclosure.

The topic of this study is important, considering that many parties needed this information as one of their considerations whenever they assess a company, not only for the stakeholders but also for the academician or researchers alike. Besides, it is also important to remember that the practice and disclosure of corporate social responsibilities are again oversee by the laws. This research's is important in showing how social responsi- 
bility activities are disclosed and reported by the company.

Referring to the research conducted by Qa'dan \& Suwaidan (2018), this research is intended to investigates the different levels of corporate social responsibility disclosure in Indonesia and also how the effects from the board characteristics, ownership structure and the company characteristics in affecting the levels of the corporate social responsibility disclosure towards sustainability report published by non-financial companies that are listed on Indonesian Stock Exchange during the year 2017-2018.

This study contributes to prove that differences in corporate governance between countries, the sample and the study period do not have an effect on corporate governance, namely the board of commissioners and ownership structure in influencing the disclosure of corporate social responsibility. This is evidenced by the leverage consistency variable which negatively has a significant effect on corporate social responsibility disclosure. This means that the high level of leverage of a company can reduce the level of disclosure of responsibility from the corporate governance system used, the type of company and the study period. This study adds a reference to research with similar topics by using sustainability reports as the dependent variable where most studies use annual reports. So that it can provide an overview of the influence of corporate governance on environmental aspects of the company. Although companies in Indonesia that publish separate sustainability reports in Indonesia are still relatively rare.

This study used two theories to explain how the board characteristics, ownership structure and also the company's characteristic could affect the level of corporate social responsibility disclosure, which are the agency theory and the legitimacy theory. Based on the agency theory, the asymmetric information that happened due to the instability of information between the agent and the principle could be decreased through the disclosure of information that are wider to the principle that include the information regarding the social responsibility that the company did (Muttakin et.al 2015) also it could decrease the agency cost that needs to be spent by the principle in order to monitor the agent (Jensen \& Meckling 1976). The legitimation theory is based on the social contract between a company and the society (Branco \& Rodrigues, 2006) which explains that a company needs to adjust their business activities with current system of values and norms, so that companies could be accepted by the society and able to keep on operate in that location. One way that can be done by companies is by disclosing their corporate social responsibility report in order to build up confidence in the society and to build up the company's reputation.

A number of prior studies had been conducted to test out which factors that could affect the level of corporate social responsibility disclosure of a company, however the results of that studies still found to be inconsistent. Qa'dan \& Suwaidan (2018) found that independent director can negatively affect the corporate social responsibility disclosure, meanwhile according to a result from a research done by Erwanti \& Haryanto (2017) and Untoro \& Zulaikha (2013), independent commissioner does not have a negative an effect towards the disclosure of company's corporate social responsibility. The presence of a woman director in affecting the level corporate social responsibility disclosure of a company brought different findings. Ibrahim \& Hanefah (2016) found that the presence of a woman director in a Jordanian company had a positive effect in improving the company's corporate social responsibility disclosure, meanwhile Qa'dan \& Suwaidan reported insignificant results on the same variable in the same country. In Indonesia, Nanda \& Rismayani (2019) found that female commissioners did not affect the corporate social responsibility disclosure.

Company characteristics become a variable that is often tested for its effect on corporate social responsibility, this is due to differences in results found by different researchers. As found by Giannarakis (2014), profitability positively affects the corporate social responsibility while leverage has a negative effect. In contrast to what was found by Laksmintaningrum \& Purwanto (2013) and Muttakin et.al (2015), there is no effect between leverage and corporate social responsibility disclosure whereas according to the results of Arjanggie \& Zulaikha's study (2015) profitability has a negatively influenced corporate social responsibility disclosure. These diverse findings make it an important topic to be reexamined to find any factors that can influence the corporate social responsibility, especially those carried out by companies in Indonesia. The diversity of the results about this topic can occur due to differences in the corporate governance systems between other countries and Indonesia, resulting in different effects on the process of supervision and management of each company. Indonesia implements a two-tier system as its corporate governance system, in contrast to other developing countries such as Jordan, Pakistan, Iran, and Malaysia implementing a one-tier system in their companies. Basically, this difference in corporate governance is related to the economic, legal, ownership structure and socio-cultural systems that exist in the country (Purbawangsa et.al 2019). In addition, the different types of companies studied and the period of study can be another reason for the variety of the results related to the corporate social responsibility disclosure's topic.

Qa'dan \& Suwaidan (2019) explained that the board is one of the components of Corporate Governance Mechanism which is essential to monitor as well as to ensure that the manager or the board to run the company well. The existence of the board can press the manager to disclose wider information to satisfy the stakeholders. Qa'dan \& Suwaidan (2018) argue that the size of the board of commissioner has an influence on the high and low levels of corporate social responsibility disclosure in the annual report. A larger board size provides many ways to connect with external stakeholders who are providers of the resources needed for the company. This in turn will put greater pressure on the board of directors to disclose the corporate social responsibility that has been undertaken as a result of tighter supervi- 
sion by the board of commissioners. Therefore, the size of the board of commissioners needs to be considered properly so that the roles and tasks are carried out to be more effective. This is in conjunction with the agency theory, where the possibility of asymmetric information and agency conflict could be curbed with the disclosed information on a wider scale, complete and thoroughly. Qa'dan \& Suwaidan (2019) and Siregar \& Bachtiar (2010) discovered that the size of the board in company had a positive impact towards the disclosure of the company's corporate social responsibility therefore the hypothesis that could be suggested is:

\section{$\mathrm{H}_{1}$ : Board size has a positive effect on corporate social responsibility disclosure}

Same as the board, the presence of an independent commissioner is expected to able to press the manager to act accordingly to the company's purposes and the stakeholders through the tighter supervision function (Qa'dan \& Suwaidan 2019). Independent commissioners have an incentive to disclose information voluntarily to protect the company's reputation. This suggests that more voluntary disclosure of information (Said 2009), including information on corporate social responsibility, will increase the transparency of all information for stakeholders. This is related to the agency theory where a tighter supervision by the independent commissioner could decrease the asymmetric information and could increase company's reputation through disclosing wider information including those that are related to social activities as part of company's obligation to the stakeholders. According to Webb in Ibrahim \& Hanefah (2016), non-independent directors in carrying out their duties have the possibility to be manipulated by the CEO so that independent directors are considered to act more effectively than non-independent directors. Qa'dan \& Suwaidan (2019); Ibrahim \& Hanefah (2016) formulated that the disclosure of corporate social responsibility positively affected by the independent commissioner. According to this fact, the hypothesis that could be suggested is:

\section{$\mathrm{H}_{2}$ : Independent commissioners has a positive effect on corporate social responsibility disclosure}

According to an argument by Gilpartick (2000) these days, most of the members of the commissioner board or the board of the companies in the world are old and there are only a few members that are young. The older members of the board have a tendency to not accept brand new things and reluctant to implement innovation on new strategies, although these people are more experienced and knowledgeable than those younger members of the board (Qa'dan \& Suwaidan, 2019). This can make the older member of the board to decrease its initiative in the social activity disclosure as a part of the responsibility of the company. Therefore, according to the research of Qa'dan dan Suwaidan (2019), the hypothesis that could be suggested is:

\section{$\mathrm{H}_{3}$ : Board age has a negative effect on corporate socia responsibility disclosure}

According to Muttakin et.al (2015) the results from previous researches showed that the presence for a women director or commissioner has a role in improving the moral legitimation of the company through social activities that were done by the company. Thus, the presence of a woman commissioner could boost the activity and disclosure of information related to company especially information about corporate social responsibility (Qa'dan \& Suwaidan, 2019) to improve the reputation of the company and to responsible to the stakeholders. This is related to Smith et.al (2006) that variety in genders could increase the appeal of a company through the improvement in the competitive advantage that is owned by the company. The hypothesis that could be suggested is:

\section{$\mathrm{H}_{4}$ : Board gender has a positive effect on corporate so- cial responsibility disclosure}

According to the agency theory, stocks that are concentrated with certain parties, in this case the board, will decrease the chances of asymmetric information from happening that will also decrease the agency conflict (Qa'dan \& Suwaidan (2019). Furthermore, the board members that owned company's shares will obtain information from sources other than the annual report, therefore will decrease the need for information that are more complete including information regarding social activities carried out as a part of the company's obligation. Qa'dan \& Suwaidan (2019) found that a concentration of board ownership impacts negatively to the corporate social responsibility disclosure the hypothesis that could be suggested is:

\section{$\mathrm{H}_{5}$ : Board of director ownership concentration has a negative effect on corporate social responsibility disclosure}

Jensen \& Meckling (1976) said that, monitoring and supervision that carried out by institutional investor on company's management could be one way to limit the budget on agency cost. This monitoring, according to the legitimation theory, could in fact press the manager to disclose the company's corporate social responsibility in order to gain the company's reputation and the society's trust so that the company will still be able to operate in a long period of time. According to Nurleni et.al (2018), companies that have dominant institutional ownerships can produce control and monitoring that are much higher towards the companies. Thus, the hypothesis that could be suggested is:

\section{$\mathrm{H}_{6}$ : Institutional ownership has a positive effect on corporate social responsibility disclosure}

Muttakin et.al (2015) states that foreign investors are more likely to be aware of the social impacts of the company and therefore increasing a more transparent accountability in disclosing for the respond from the effects on the society through the disclosure of social activities. This is becoming a part of company's obligation to the stakeholders. This is supported the agency theory and the legitimation theory where the disclosure of information about social responsibility of a company 
could decrease the likelihood of asymmetric information with the investor and could increase the reputation and gives a positive signal to the market regarding the company's performance. Muttakin et.al (2015) found that foreign ownership positively affects the corporate social responsibility disclosure, so that the hypothesis that could be suggested is:

\section{$\mathrm{H}_{7}$ : Foreign ownership has a positive effect on corpo- rate social responsibility disclosure}

According to the agency theory explained by Giannarakis (2014), companies with higher profits, tend to give a more complete and thorough information to support their positions and to compensation plan. Purbawangsa et.al (2019) added that a further disclosure of information that are wider is aimed to convince the investor that companies were not only concern themselves with their short-term aim which is to find profit, but to also their long-term aim which is to increase the value of companies. On the other hand, in regards with the legitimation theory, companies with higher profits will motivate the management to disclose an even more information to convince the stakeholders with the company's performance (Muttakin et.al 2015). Thus, the hypothesis that could be suggested is:

\section{$\mathrm{H}_{8}$ : Profitability has a positive effect on corporate so- cial responsibility disclosure}

A high level of leverage would make the company to decrease the information disclosure including information about corporate social responsibility because it is requiring procedures and a lot of money (Giannarakis, 2014). This supports the agency theory that when a company with a high level of leverage, that company will have a tendency to limit the disclosure of information about the company in order to avert the attention of the debtholder away from the company's performance. Furthermore, according to the legitimacy theory, the company will cut back its disclosure on bad information about the company in order to keep the people's trust. According to this theory, the hypothesis that could be suggested is:

\section{$\mathrm{H}_{9}$ : Leverage has a negative effect on corporate social responsibility disclosure}

\section{RESEARCH METHODS}

Variable used in this study is divided into 3 groups which are dependent, independent and control variables. Dependent variable is the corporate social responsibility that measured using dummy variable whose score will then be calculated. The standard in measuring the variable is the GRI disclosure standard.

The board of commissioners is a part of the GCG mechanism as a supervisory function for company management. In the research of Qa'dan \& Suwaidan (2018), the measurement of the board of commissioners is done by counting the number of directors on the board, which if adjusted for corporate governance mechanisms in Indonesia becomes the number of commissioners in the company. Independent commissioners are part of the board of commissioners who are not affiliated with the company. Using the same method with Qa'dan Suwaidan (2018) the independent commissioner variable is measured by calculating the percentage of independent commissioners to the total number of commissioners in the company. Age of the board measured by calculating the average age of the board's member and the board gender measured by calculating the percentage of women members on the commissioner board. Ownerships concentration of the board measured by calculating the percentage of shares members of the board, institutional ownership measured by calculating the percentage of shares owned by institutional investors meanwhile foreign ownerships measured by calculating the percentage of shares owned by foreign investors. Profitability measured using ROA and leverage measured by calculating the percentage of the total liabilities divided by the total assets. The control variables used for controlling the influence of the independent variable towards the dependent variables so that they would be affected by factors outside of this study, that is variable was the size of the company that is measured using a natural logarithm from total assets, age of the company measured by finding the total sum of years since the company has been listen at BEI until the period of study, and the size of the auditor company measured using dummy variable where it would determine whether or not the company would be audited by Big- 4 audit firm or not.

The population used for this study is non-financial companies listed on the Indonesian stock exchange and published sustainability report in 2017-2018. The aim for the choosing this companies as a population of this study because it is still a rarity of companies in Indonesia to publish a sustainability report, separate from their annual report and because non-financial companies are big and complex where their operation has impacts towards the society and the surroundings both directly and indirectly. The research samples obtained by using purposive sampling method with certain criteria so that they suit the purpose of the research. The criteria as follows: the company published a separate sustainability report from the annual report during the study period; the company used GRI Standards as the standard for disclosure in its sustainability reports during the research period; the company provides the information needed for research. The year 2017 and 2018 were chosen as the period used in the research so that they could reflect the situation and condition of business environment nowadays.

$$
\begin{aligned}
& C S R D=\alpha+\beta_{1} B S I Z E+\beta_{2} N E D+\beta_{3} D A G E \\
& +\beta_{4} D G E N+\beta_{5} B O W N+\beta_{6} I O W N \\
& +\beta_{7} F O W N+\beta_{8} P R O F+\beta_{9} F L E V \\
& +\beta_{10} F S I Z E+\beta_{11} F A G E \\
& +\beta_{12} A U D I T+\varepsilon \text {...... }
\end{aligned}
$$

$\alpha=$ Constant; $\beta 1-12=$ Regression Coefficient; $\varepsilon=$ Error; BSIZE $=$ Board Size; NED = Independent Commissioner; DAGE = Board Age; DGEN = Board Gender; BOWN = Ownership Concentration; IOWN = Institutional Ownership; FOWN = Foreign Ownership PROF $=$ Profitability; FLEV = Leverage; FSIZE = Company's size; FAGE = Company's age; AUDIT = Audit Company's Size 
This study used statistic descriptive, classical assumption testing and multiple regression method to test the hypothesis that suggested. The regression model used is shown by equation 1 . The assessment of model fit (Goodness of Fit) from the regression model of the study was carried out as a criterion in using multiple regression analysis with a significance level of $5 \%$ in determining whether a hypothesis was accepted or rejected. From the table 1, it is shown that the number of samples in this study were 20 companies out of a total population of 43 companies. This research was done during 2 periods resulted in the total observation of 40 . This sample resembles a population $46.51 \%$ out of $100 \%$.

\section{RESULTS AND DISCUSSIONS}

The table 2 is the result of descriptive statistics that gives description of each variables used in the study. This description could be seen from the average value, standard deviation, and the minimum and maximum value (Ghozali,2016). From the table 2, we can see that the corporate social responsibility dine by companies are only $38.91 \%$ on average with the lowest disclosure at $21.05 \%$ and the highest at $53.95 \%$. The average members of the board size within a company is 6 where $38.96 \%$ of which are independent commissioner and $11.06 \%$ are women. Furthermore, from the table it is known that the members of the commissioner board are on average 57 years old which means that board members are old, and thus proving the opinion of Gilpartick (2000), where most members board were old.

Corresponding to the structure of ownership, companies had an average institutional ownership of $34.14 \%$ and foreign ownership of $39.72 \%$. Within the companies, there were board ownerships of $0.47 \%$ which means that companies' shares are not concentrated on the board. Companies on average made 5.48\% of profit from their asset and they also had average debts of $54.40 \%$.

Table 3 show the results of the Asymp. sig is 0.200

Table 1. Research Sample Description

\begin{tabular}{|c|c|c|c|}
\hline No. & Description & Total & Percentage \\
\hline 1. & $\begin{array}{l}\text { Non-Financial Companies } \\
\text { listed on BEI and Pub- } \\
\text { lished sustainability report } \\
\text { separate from the annual } \\
\text { report from the year 2017- } \\
2018\end{array}$ & 43 & $100 \%$ \\
\hline 2. & $\begin{array}{l}\text { Non-Financial companies } \\
\text { that did not publish sus- } \\
\text { tainability report using the } \\
\text { GRI standard during the } \\
\text { study }\end{array}$ & (20) & $(46.51 \%)$ \\
\hline 3. & $\begin{array}{l}\text { Companies with incom- } \\
\text { plete data along the course } \\
\text { of study }\end{array}$ & (1) & $(2.32 \%)$ \\
\hline & $\begin{array}{l}\text { Sample Companies } \\
\text { Outlier }\end{array}$ & $\begin{array}{l}22 \\
(2)\end{array}$ & $\begin{array}{c}51.16 \% \\
(4.65)\end{array}$ \\
\hline \multicolumn{2}{|c|}{ Total samples under the criteria } & 20 & $46.51 \%$ \\
\hline
\end{tabular}

Table 2. Descriptive Analysis

\begin{tabular}{cccccc}
\hline Variable & N & Min & Max & Mean & $\begin{array}{c}\text { Std } \\
\text { Dev }\end{array}$ \\
\hline CSR & 40 & 21.05 & 53.95 & 38.91 & 9.04 \\
BSIZE & 40 & 3 & 11 & 6.22 & 1.73 \\
NED & 40 & 28.57 & 80.00 & 38.96 & 11.18 \\
DAGE & 40 & 43.83 & 69.67 & 57.48 & 5.16 \\
DGEN & 40 & 0 & 33.33 & 11.06 & 12.27 \\
BOWN & 40 & 0 & 0.47 & 0.04 & 0.11 \\
IOWN & 40 & 0.94 & 97.47 & 34.13 & 32.70 \\
FOWN & 40 & 0.09 & 96.39 & 39.72 & 34.98 \\
PROF & 40 & -16.78 & 44.82 & 5.48 & 10.33 \\
FLEV & 40 & 14.47 & 174 & 54.40 & 29.23 \\
FSIZE & 40 & 28.80 & 33.47 & 30.81 & 1.08 \\
FAGE & 40 & 3 & 41 & 19.85 & 11.90 \\
& & & & Frequency & Percent \\
AUDIT & & Big-4 & & 30 & 75 \\
& & auditor & & 10 & 25 \\
& & Non- & & & \\
& & Big-4 & & & \\
\hline
\end{tabular}

Source: secondary data processed (2020)

which is greater than the significance value of 0.05 . The tolerance value generated by each independent variable is more than 0.1 and VIF value is less than 10, Asymp. Sig. (2-tailed) from the results of the run test is 0.873 , which is $>0.05$. Sig value. (2-tailed) produced by each independent variable at Unstandardized Residual is $>0.05$. This means that the data used as the research sample is free from of normality, multicollinearity, autocorrelation and heteroscedasticity issue.

This study used the multiple linear regression model and therefore classical assumption testing was required in order to find out which regression model would have to be used free from the problems that could hinder the interpretation of the research results (Ghozali, 2016). After the classic assumption testing had been done and deemed that the regression model was the best model for it was free from normality, multicollinearity, heteroscedasticity, and autocorrelation.

Table 4 shows the conclusion as the result of the regression analysis. From the table, it could be seen that the dependent variables significantly affected by the all of the independent variables $(\mathrm{F}=3.115 \mathrm{Sig} .0 .007)$. Adjusted $\mathrm{R}$ Squared shows the determination coefficient which means that the dependent variable which is the disclosure of the corporate social responsibility could be explained through the independent variables which is $39.4 \%$ and the rest which is $60.6 \%$ explained by other factors.

According to the results of the table 4, the variables of the proportion of women as members of the board, concentration of ownerships by the board, profitability and leverage negatively influenced the corporate social responsibility disclosure with the level of significant of five percent. Meanwhile, other variables which are the 
Table 3. Classic Assumption Test Result

\begin{tabular}{|c|c|c|c|c|}
\hline \multirow{2}{*}{ Variable } & \multicolumn{2}{|c|}{$\begin{array}{c}\text { Collinearity Sta- } \\
\text { tistic }\end{array}$} & \multicolumn{2}{|c|}{ Glejser Result } \\
\hline & $\begin{array}{l}\text { Toler- } \\
\text { ance }\end{array}$ & VIF & $\mathbf{t}$ & Sig \\
\hline BSIZE & 0.574 & 1.741 & -0.219 & 0.828 \\
\hline NED & 0.233 & 4.300 & 0.992 & 0.330 \\
\hline DAGE & 0.656 & 1.525 & -1.453 & 0.158 \\
\hline DGEN & 0.554 & 1.805 & 0.998 & 0.327 \\
\hline BOWN & 0.471 & 2.125 & -0.191 & 0.850 \\
\hline IOWN & 0.198 & 5.042 & -0.258 & 0.798 \\
\hline FOWN & 0.278 & 3.594 & -1.157 & 0.257 \\
\hline PROF & 0.229 & 4.367 & -0.666 & 0.511 \\
\hline FLEV & 0.264 & 3.788 & 0.232 & 0.818 \\
\hline FSIZE & 0.645 & 1.550 & 0.900 & 0.376 \\
\hline FAGE & 0.393 & 2.545 & -1.096 & 0.283 \\
\hline \multirow[t]{2}{*}{ AUDIT } & 0.575 & 1.738 & -0.224 & 0.824 \\
\hline & $\mathrm{d}$ & $\mathrm{dl}$ & $\mathrm{du} \quad 4-\mathrm{dl}$ & $4-\mathrm{du}$ \\
\hline $\begin{array}{l}\text { Durbin- } \\
\text { Watson }\end{array}$ & 2.309 & 0.8404 & $2.3089 \quad 3.1596$ & 1.6911 \\
\hline \multicolumn{4}{|c|}{ Asymp. Sig One-Simple Kolmogorov-Smirnov } & $0.200^{\mathrm{c}, \mathrm{d}}$ \\
\hline \multicolumn{4}{|c|}{ Asymp. Sig Run Test } & 0.873 \\
\hline
\end{tabular}

Source: secondary data processed (2020)

size of the board, independent commissioner, age of the board, institutional ownerships, foreign ownerships and control variables which made up of size of the company, age of the company and size of the company did not affect towards the corporate social responsibility disclosure since they had a significant higher level that was more than five percent.

Effect of Board Size, Independent Commissioners, and Board Age on Disclosure of Corporate Social Responsibility

The result of the multiple regression analysis showed that the of board size, independent commissioner and age of the board variable had a significant value of more than five percent. That means board size, independent commissioner and the age of the commissioner board partially did not affect the corporate social responsibility disclosure and thus $\mathrm{H}_{1}, \mathrm{H}_{2}$, and $\mathrm{H}_{3}$ were rejected. The size of the board does not affect the corporate social responsibility disclosure according to Sukasih \& Sugiyanto (2017) because the small amount makes the supervision of the board of management and directors less effective so that it fails to put pressure on managers and directors to disclose wider information including about responsibility social enterprise in order to reduce information asymmetry. This is shown in the results of the descriptive analysis where the number of commissioners owned by the company which is the research sample is only 6 people. In line with this, the small number of members of the board has an impact on the limited number of independent commissioners can reduce the effectiveness of supervision to encourage corporate social responsibility practices and disclosure in order to reduce the possibility of information asymmetry, so that the results of this study fail to support agency theory. Furthermore, limited number of independent commissioners makes them unable to influence decision making especially relating to decisions about practice and disclosure of corporate social responsibility (Widyastari \& Sari 2018). Erwanti \& Haryanto (2017) added that the existence of independent commissioners in the company is only to fulfill the regulations to have at least $30 \%$ independent commissioners on the board of commissioners so that their existence does not show their independence in supervising the company.

Based on descriptive analysis, the members of the board of commissioners in the sample companies have an average age of 57 years, which indicates that the majority of board members are aged and do not affect the size of the corporate social responsibility disclosed in the sustainability report. Even though there is a board of commissioners who is 43 years old, disclosure of corporate social responsibility remains low. This is evidenced by the results of the regression analysis; it can be seen that the young age of board members cannot influence the level of corporate social responsibility disclosure.

\section{The Influence of Board Gender on Corporate Social Responsibility Disclosure}

The proportion of woman director found to have a negative influence on corporate social responsibility disclosure, so the hypothesis suggested that the board gender has a positive effect on corporate social respon-

Table 4. Regression Analysis Result

\begin{tabular}{lccccc}
\hline Variable & B & Beta & t-value & Sig. & VIF \\
\hline BSIZE & -1.431 & -0.274 & -1.666 & 0.107 & 1.741 \\
NED & 0.215 & 0,263 & 1.016 & 0.318 & 4.300 \\
DAGE & 0.436 & 0.249 & 1.618 & 0.318 & 1.525 \\
DGEN & -0.382 & -0.518 & -3.094 & 0.005 & 1.805 \\
BOWN & -38.486 & -0.478 & -2.633 & 0.014 & 2.125 \\
IOWN & -0.028 & -0.101 & -0.360 & 0.721 & 5.042 \\
FOWN & 0.031 & 0.120 & 0.506 & 0.617 & 3.594 \\
PROF & -0.602 & -0.688 & -2.642 & 0.014 & 4.367 \\
FLEV & -0.252 & -0.814 & -3.356 & 0.002 & 3.788 \\
FSIZE & -0.180 & -0.022 & -0.139 & 0.891 & 1.550 \\
FAGE & -0.142 & -0.186 & -0.938 & 0.357 & 2.545 \\
AUDIT & -3.309 & -0.160 & -0.976 & 0.338 & 1.738 \\
(Con- & 47.967 & & 1.181 & 0.248 & \\
stant) & & & & & \\
$R^{2}$ & 0.581 & & & & \\
Adjusted & 0.394 & & & & \\
$\mathrm{R}^{2}$ & & & & & \\
F & 3.115 & & & & \\
Sig. & 0.007 & & & & \\
\hline
\end{tabular}

Source: secondary data processed (2020)

Notes: significant at $5 \%$ 
sibility disclosure must be rejected. According to Pajaria et.al (2016), women have a tendency to avoid risk which then raises a cautious attitude in taking action and making decisions. This will potentially reduce the practice and disclosure of social activities undertaken by the government. In addition, according to Hamdani \& Hatane (2017) in Indonesia there is still a stereotype that it is more appropriate for men to hold leadership positions than women. This will reduce the role of women in the company especially in encouraging the practice and corporate social responsibility disclosure. This can be motivated by the lack of qualifications and abilities possessed by women in various developing countries (Muttakin et.al 2015). Nevertheless, the results of this study failed to support the results found by Qa'dan \& Suwaidan (2018).

\section{The Influence of Profitability on Corporate Social Re- sponsibility Disclosure}

The profitability variable has similar results to the board gender variable. This is because the regression coefficient result that is negative and significant at five percent, so $\mathrm{H}_{8}$ must be rejected. Based on the legitimacy theory revealed by Arajnggie \& Zulaikha (2015), companies do not feel the need to report information that can adversely affect the financial performance when their profits are high. The manager will disclose information other than economic information such as information about social activities carried out by the company when its financial performance decreases. This is intended to provide good news in order to maintain the company's good image in the eyes of the public (Arjanggie \& $\mathrm{Zu}$ laikha 2015). These findings contradict most studies such as Giannarakis (2014), Muttakin et.al (2015), Purbawangsa et.al (2019) who find that profitability brings positive impact to the corporate social responsibility. This is due to the low profitability generated by companies in Indonesia that affects the low corporate social responsibility disclosure in the sustainability report.

\section{The Influence of Board of Director Ownership Con- centration and Leverage on Corporate Social Respon- sibility Disclosure}

Based on the results of multiple regression analysis, ownership concentration of directors and leverage variable produces a significant value of less than five percent, so that $\mathrm{H}_{5}$ and $\mathrm{H}_{9}$ are accepted. Although this result fails to support the agency theory that shares concentrated in certain parties can reduce information asymmetry and agency conflict which will reduce the pressure for reporting more complete information, one of which is information relating to social activities that are the responsibility of the company due to the low level of company's share held by the board in the company which is only $0.04 \%$, but the board of directors can still get more information other than the annual report (Qa'dan \& Suwaidan, 2019). Thus, this is can still reduce the need for the board of directors for disclosure of information, especially regarding corporate social responsibility.
This finding is in line with agency theory and legitimacy theory, where companies with high leverage reaching $174 \%$. This is will limit the social responsibility information disclosed by the company to avoid the spotlight of creditors and to maintain a good image to keep the public's trust. The results of this study are consistent with Giannarakis (2014), that when the leverage of the company is high, the company will trying to limit the reporting of corporate social responsibility information because it will require expensive costs since the company bears high interest costs and will be more concerned with how they pay off their debts (Marfuah \& Cahyono, 2011). Therefore, the higher the leverage of a company, it will reduce the tendency of companies to practice and disclose the corporate social responsibility. This finding is not consistent with Muttakin et.al (2015); Untoro \& Zulaikha (2015); Laksmitaningrum \& Purwanto (2013); Siregar \& Bachtiar (2010).

\section{The Influence of Institutional Ownership and Foreign Ownership on Corporate Social Responsibility Dis- closure}

Regarding the ownership structure in the company, institutional and foreign ownership does not affect the level of corporate social responsibility disclosure. Seen from the results of multiple regression analysis, the two variables produce more than five percent significant value so that $\mathrm{H}_{6}$ and $\mathrm{H}_{7}$ are rejected. The lack foreign and institutional ownership impact in influencing the corporate social responsibility is because investors are more likely to focus on the success of the company's economic performance alone so that it ignores other aspects of the company such as social aspects (Irjayanti 2014). This makes the company does not feel the need to legitimize its social activities which fail to support the legitimacy theory. In addition, this study also failed to support the agency theory because the presence or absence of information about social responsibility by the company did not cause information asymmetry in the company. The results of this study support the research results of Qa'dan \& Suwaidan (2018); Irjayanti (2014); Siregar \& Bachtiar (2010).

\section{The Influence of Control Variables on Corporate So- cial Responsibility Disclosure}

Control variables were found to have no effect on corporate social responsibility disclosure based on the results of the regression analysis which showed that the significant value generated exceeded five percent. According to Pakpahan \& Rajagukguk (2018) the reason company size cannot affect the disclosure of information regarding social responsibility can occur because regardless of the size of the company, they will still get the attention of the public for the activities they carry out, so that both companies with large and small sizes have their obligations. remain the same in carrying out social activities as part of the responsibility and disclosure. But in fact, from the results shown in this study, both companies that have large and small sizes are still unable to encourage high social responsibility disclosure. 
Company age has no role in influencing disclosure of corporate social responsibility. It is shown by the results of descriptive statistics, that there are companies that have only been listed on the IDX for 3 years and some have been registered for 41 years. This is due to the existence of Law No. 40 of 2007 which states that companies are required to carry out social responsibility and disclose them, so that each company has the same obligation to carry out and disclose its social and environmental activities regardless of how long the company has been in existence. This finding contradicts the legitimacy theory which states that companies that are longer established will provide more detailed information to maintain public trust. Furthermore, Law No. 40 of 2007 provides an obligation for every company to practice and disclose social responsibility, this make the auditors feel there is no need to recommend their client companies to report their social activities (Nanda \& Rismayani, 2019) in annual reports and sustainability reports because of this. it has become the obligation of each company. Therefore, both companies that are audited by auditors from Big-4 and non-Big-4 audit firm should report information on their social activities without the need for suggestions or recommendations from the auditors who audited their companies. So, it does not support the legitimacy theory because companies do not feel the need to increase public trust through disclosing their social activities through reports that will be audited by auditors from Big-4 and non-Big-4 audit firm.

\section{CONCLUSIONS}

This study aims to examine the influence of the board characteristic, ownership structure and company characteristic on corporate social responsibility disclosure that is conducted on non-financial companies listed on the IDX and publishes sustainability reports in 20172018. Based on the results of various tests conducted, we can be concluded that corporate social responsibility conducted by Indonesian companies are still low. Variables that can influence the low level of disclosure are board' gender, directors' ownership concentration, profitability, and leverage. While other variables have not been able to influence the corporate social responsibility disclosure. The results of the study can be influenced by the small number of companies that disclose their corporate social responsibility in the sustainability report compared to the number of influences tested on the disclosure of corporate social responsibility itself.

This study contributes in proving that differences in corporate governance between countries, the sample and the study period do not influence the characteristics of corporate governance, namely the board and ownership structure in influencing the corporate social responsibility disclosure. This is evidenced by the consistent leverage variable which negatively and significantly affects the corporate social responsibility disclosure. This means that the high leverage of a company can reduces the level of corporate social responsibility disclosure regardless of the corporate governance system used, the type of company and the period of study.
This study has limitations in the number of observations that are very limited and only refers to one disclosure standard, namely the GRI Standard, making it difficult to generalize if companies apply different indices to different reports. Suggestions that can be given in further research is to expand the scope of research to increase the number of observations, using disclosure indexes that are more generalizable for all types of companies and all types of reports such as ISO 26000. This study also has not added other variables that can influence corporate social responsibility disclosure such as managerial ownership and government ownership.

\section{REFERENCES}

Arjanggie, A. R., \& Zulaikha. 2015. Pengaruh Profitabilitas dan Umur Perusahaan Terhadap Pengungkapan Tanggung Jawab Sosial Perusahaan Studi Empiris pada Perusahaan Industri Dasar dan Kimia yang Terdaftar di Bursa Efek Indonesia. Diponegoro Journal of Accounting, 4(3).

Branco., M. C., \& Rodrigues, L. L. (2006). Communication of Corporate Social Responsibility by Portuguese Banks: A Legitimacy Theory Perspective. Corporate Communications: An International Journal, 11(3), 232-248.

Erwanti, Y., \& Haryanto. (2017). Pengaruh Ukuran Perusahaan, Profitabilitas, Dewan Komisaris, Komite Audit, Dan Kualitas Audit Terhadap Pengungkapan Informasi Pertanggungjawaban Sosial. Diponegoro Journal of Accounting, 6(4), 295-308.

Fahmi, I. (2017). Etika Bisnis, Teori, Kasus, dan Solusi. Cetakan ke IV. Bandung : Alfabeta

Ghozali, I. (2016). Aplikasi Multivariete dengan Program IBM SPSS 23. Cetakan ke VIII. Semarang : Badan Penerbit Universitas Diponegoro.

Giannarakis, G. (2014). Corporate Governance and Financial Characteristic Effects on The Extent of Corporate Social Responsibility Disclosure. Social Responsibility Journal, 10(4), 569-590.

Hamdani, Y., \& Hatane, S. E. (2017). Pengaruh Wanita Dewan Direksi terhadap Firm Value melalui Firm Performance sebagai Variabel Intervening. Business Accounting Review, 5(1), 121-132.

Ibrahim, A. H., \& Hanefah, M. M. (2016). Board Diversity and Corporate Social Responsibility in Jordan. Journal of Financial Reporting and Accounting, 14(2), 279-298.

Irjayanti, D. P. P. (2014). Pengaruh Kepemilikan Institusional, Umur Perusahaan, Dan Ukuran Perusahaan Terhadap Corporate Social Responsibility Disclosure (Studi Pada Perusahaan Manufaktur Terdaftar Di Bursa Efek Indonesia. Forum Ilmiah Pendidikan Akuntansi, 2(2).

Jensen., M. C., \& Meckling, W. H. (1976). Theory of The Firm Manajerial Behaviour, Agency Cost and Ownership structure. Journal of Financial Economics, 3(4), 305-360.

Laksmitaningrum, C. F., \& Purwanto, A. (2013). Analisis Pengaruh Karakteristik Perusahaan, Ukuran Dewan Komisaris Dan Struktur Kepemilikan Terhadap Pengungkapan CSR (Studi Empiris Pada Perusahaan Manufaktur Yang Terdaftar Di Bursa Efek Indonesia Tahun 2009-2011). Diponegoro Journal of Accounting, 2(3), 1-10.

Marfuah \& Cahyono, Y. D. (2011). Karakteristik Perusahaan dan Pengungkapan Tanggung Jawab Sosial Perusahaan. Jurnal Akuntansi dan Auditing Indonesia, 15(1), 
103-119.

Muttakin, M. B., Khan, A., \& Subramaniam, N. (2015). Firm Characteristic, Board Diversity and Corporate Social Responsibility. Pacific Accounting Review, 27(3), 353372.

Nanda, U. L., \& Rismayani, G. (2019). Pengaruh Gender Diversity, Profitabilitas, Ukuran Perusahaan, Ukuran KAP Terhadap Pengungkapan Tanggung Jawab Sosial Perusahaan. Jurnal Riset Keuangan Dan Akuntansi, 5(1), 66-74.

Nurleni, N., Bandang, A., Darmawati, \& Amiruddin. (2018). The Effect of Managerial and Institutional Ownership on Corporate Social Responsibility Disclosure. International Journal of Law and Management, 60(4), 979-987.

Pakpahan, Y., \& Rajagukguk, L. (2018). Analisis Pengaruh Profitabilitas, Ukuran Perusahaan, Ukuran Dewan Komisaris, dan Media Exposure Terhadap Pengungkapan Tanggung Jawab Sosial. Jurnal Akuntansi, 18(2), 197-218.

Pajaria, Y., Meutia, I., \& Widiyanti, M. (2016). Pengaruh Diversitas Dewan Direksi dan Komisaris, Ukuran Perusahaan, dan Profitabilitas Terhadap Pengungkapan Corporate Social Responsibility Perusahaan Sektor Manufaktur Yang Terdaftar Di Bursa Efek Indonesia. Akuntabilitas: Jurnal Penelitian Dan Pengembangan Akuntansi, 10(2), 177-200.

Purbawangsa, I. B. A., Solimun, S., Fernandes, A. A. R., \& Rahayu, S. M. (2019). Corporate Governance, Corporate Profitability Toward Corporate Social Responsibility Disclosure and Corporate Value (Comparative Study In Indonesia, China and India Stock Exchange In 2013-2016), Social Responsibility Journal, 16(7), 983-999.

Qa'dan, M. B. A., \& Suwaidan, M., S. (2018). Board Composition, Ownership Structure and Corporate Social Responsibility Disclosure: The Case of Jordan. Social Responsibility Journal, 15(1), 28-46.

Sukasih., A., \& Sugiyanto, E. (2017). Pengaruh Struktur Good Corporate Governance dan Kinerja Lingkungan Terhadap Pengungkapan Corporate Social Responsibility (Studi Pada Perusahaan Manufaktur di Bursa Efek Indonesia Periode 2011-2015). Riset Akuntansi dan Keuangan Indonesia, 2(2), 121-131.

Smith, N., Smith, V., \& Verner, M. (2006). Do Woman in Top Management Affect Firm Performance? A Panel Study of 2,500 Danish Firms. International Journal of Productivity and Perfomance Management, 55(7), 569-593.

Untoro, D. A., \& Zulaikha. (2013). Pengaruh Karakteristik Good Corporate Governance (GCG) Terhadap Luas Pengungkapan Corporrate Social Responsibility (CSR) di Indonesia (Studi Empiris pada Perusahaan Perbankan yang Terdaftar di BEI Tahun 2008-2011). Diponegoro Journal of Accounting, 2(2).

Siregar, S. V., \& Bachtiar, Y. (2010). Corporate Social Reporting: Empirical Evidence from Indonesia Stock Exchange. International Journal of Islamic and Middle Eastern Finance and Management, 3(3), 241-252.

Widyastari, N. K. W., \& Sarim M. M. R. (2018). Pengaruh Ukuran Perusahaan, Proporsi Dewan Komisaris Independen, dan Kepemilikan Asing pada Pengungkapan Corporate Social Responsibility. E-Jurnal Akuntansi, 22(3), 1826-1856 